\title{
A study on the effect of financial reports on firms' share value
}

\author{
Hassan Ghodrati $^{\mathrm{a}^{*}}$ and Gholamhassan Taghizad
}

Department of Management and accounting, Kashan Branch, Islamic Azad University, Tehran, Iran

\section{CHRON I C L E A B S T RACT}

Article history:

Received January 20, 2014

Accepted 5 July 2014

Available online

August 202014

Free Cash Flow

Internet financial reporting

Stock price

Evaluation

\begin{abstract}
Technology development has influenced various fields, and financial field is one of them. Applying new technologies in financial field has led to the emergence of a new kind of reporting called Internet Financial Reporting, and is used increasingly day by day due to the increasing use of internet. Adopting this kind of reporting has caused changes in the process of informing stockholders and other users. Since increasing and updating information quality can influence on decision makers to buy/sell their stock certificate, and, on the other hand, the demand for buying and selling stock certificate might influence on stock price, we aimed to evaluate the effect of internet financial reporting on the stock price of listed companies in Tehran Stock Exchange. For this purpose, a group of companies was selected as the experimental group, and some others as the control group. Then, we investigated stock price changes in both groups, and compared changes. The results indicate that internet financial reporting had no effect on the stock price in the investigated companies.
\end{abstract}

\section{Introduction}

XBRL that is called an extendible (extendable) financial reporting language enables information users to exert their required information easily from the financial statements, to analyze and to disintegrate the data. Internet financial reporting has various advantages for its suppliers and users, some of which can be discussed below:

Internet financial reporting versus traditional financial reporting in which paper was used for offering necessary reports is less costly, especially in large companies, because of the great number of stock holders and people eagerness to know about these companies properties in order to invest in them.

This kind of reporting can bring about large amount of information for users during a short period of time that causes the companies to become famous and popular amongst investors, credit-suppliers and other users ending in increasing demands for buying companies stocks, respectively resulted in prices increase at last. Although mentioned advantages in Internet financial reporting is remarkable, yet there are some difficulties in its use caused that some companies are still using traditional financial reporting.

*Corresponding author

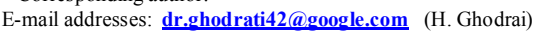




\section{Research background}

Tornatzki (1990) considered various characteristics like quality and efficient manpower as important factors within the organization for adopting financial reporting on internet. Iacovou et al. (1995) concluded that as the size of companies increases, the amount of their profit increases, which leads to more benefits from this emerging media (internet) for larger commercial units due to having more sources. Xiao et al. (1996) mentioned that larger companies apply internet reporting more, due to being answerable to more extensive informational demands. Petravick and Gillelt (1996) concluded that since May 1996, 103 out of 150 studied companies have websites, of which 83 companies put their own financial information on their websites. Louwers et al. (1996) suggested that only 35 companies out of 150 studied companies had disclosed their financial information on websites and 42 ones had not disclosed such information despite having websites. Wallman (1997) believed that internet could provide unlimited access to details of companies' information. Gray and Debreceny (1997) concluded that $67 \%$ of successful companies (34 out of 50) had had an annual report website, $98 \%$ had had information websites, and $36 \%$ had disclosed their independent auditor reports on their own websites. Pirchegger et al. (1999) investigated the relationship between company size and quality of information presented in Austrian companies. They concluded that the effect of company size and its profitability on internet disclosure in Austria had not had the same as German companies.

Craven and Marston (1999) investigated some large UK companies and concluded that company size had direct relation with the amount of use and disclosure, but there was no relation between the kind of industry and the amount of disclosure. Hedlin (1999) studied the websites of Swedish companies and reported that $83 \%$ companies disseminated their financial statements on internet and larger companies disclosed more information on internet. Craven and Marston (1999) found out in a research on 206 companies in London Stock Exchange that larger companies, more probably, disseminated their financial information on internet. They, also, found that there was no relationship between the kind of industry and the kind and amount of financial information disclosure on internet.

Ahmed and Courtis (1999) discovered, from a comprehensive investigation on 28 surveys studying disseminating financial information on internet, that there was a significant relation between company size and level of financial information disclosure. Ashbaugh et al. (1999) studied 290 large companies, from 1994 to 1996 and concluded that company size was the only factor, which was able to predict internet reporting for companies. They, also, specified the variance of each industry. Trites (1999) concluded that internet could improve the process of customizing reports. Beattie (1999) stated that reporter units must present their information as prepared packages represented in various formats in order to meet the informational demands of various users. Lymer (1999) selected 50 companies from London Stock Exchange and found that $92 \%$ of them had websites, and 52\% presented their financial reporting on their own homepages. A similar survey on Finish companies indicated that 90.2 of them had websites to present their information. Pirchegger and Wagenhofer (1999) selected 2 German and Austrian companies for their research study. They proved that company size could influence on the amount of information disclosure in websites. Moreover, there was a direct relationship between the increase in stock distribution of companies and the increase in information disclosure of websites. Debreceny ( 1999) selected a sample of 660 companies out of 22 countries all around the world and concluded that company size and being in stock market list could influence on the amount of information presentation on internet.

Bernan and Hourigan (2000) concluded from their survey that there was a significant positive relationship between reporting on internet with the kind of industry. This relation might be the result of the fact that different industries had different information disclosing expenses, which were exclusive to that industry. Arthur Anderson (2001) found out that $94 \%$ of companies, among the selected sample of 350 leading companies, had websites; and $88 \%$ of them used internet to present their financial information, including annual reports. In addition, in their survey, there was a direct relation with the decrease in company size and the amount of internet usage. Debreceny and Gray 
(1999) concluded form their survey that the extensible language of financial report could allow users to have an easy access to the financial reporting information available on websites. According to Tidd and Bessant (2001), organization's capacity to predict and respond to the changes in markets and industry might be of critical importance in internet financial reporting. Bonson and Escobar (2002) concluded from their research study that as company size enlarges, the number of outside users for company's information increases too. Larran and Giner (2002) concluded from their research study that the lower cost of providing and disseminating information on internet for larger companies were the main motivation for internet reporting. Tariq Ismail (2002) investigated the factors influencing on disclosing financial information on internet in 128 companies of Middle Eastern countries. They reported that there was a significant relationship between disclosing financial information on internet and profitability, company size and company leverage.

Larran et al. (2002) studied internet financial reporting in 144 stock exchange companies in Madrid. Their results showed that there was a significant relationship between financial leverage, stockholders' salary revenue, and the amount of disclosed information on internet. Haasbroek (2002) studied the relation between digital annual financial report and company's characteristics. Their results indicated that there was a significant relation between the kind of industry and digital financial reports. Debreceneny (2002) stated that internet reporting could decrease the conflict over benefits between managers and investors, and consequently representation and investments' expanses, and it could increase the value of company. Ettredge et al. (2002) investigated the levels of disclosure for US firms in 17 and concluded that $82 \%$ of such companies had websites in 1998, and large companies used internet reporting more than others did. Beattie and Pratt (2003) studied the characteristics and preferences of various groups in terms of internet reporting. Rotchanakitumnuai and Speece (2003) concluded that cultural factors might have an important impact on internet usage. Lawson et al. (2003) studied Australian firms and concluded that communication with government and industrial associations played essential role on internet adoption. Beattie and Pratt (2003) proved that financial managers would not prefer applying XBRL as a financial web reporting format.

Lymer and Debreceny (2003) concluded from their research study that internet reporting was more common in countries adopting IT, infrastructures, and developed stock exchange. Allam et al. (2003) studied company size and reporting methods and found out that there were different reporting methods in countries within different territories. Marston and Leow (1998) did not observe a significant relationship between financial information disclosure and the kind of industry. They indicated that there was a significant relationship between the type of industry and the amount of information disclosure on internet. Hodge et al. (2004) investigated XBRL adoption in a research environment. Simpson and Docherty (2004) observed similar results to Australian environment in England, but they concluded that governments and societies had no effect on internet reporting. Marston and Craven (2004) indicated that there was no significant relationship between company size and the amount of information disclosure on websites. Bager and Lefrell (2005) compared the process of current and traditional financial reporting to the changes resulting from XBRL. They reported that XRBL could influence on the influential control of annual reports, the improvement of reporting to clients and the ability of computer-based controls. Chang and Järvenpää (2005) studied the development of XBRL standards in terms of institutional changes in and within the groups benefiting from financial reporting chain. Boritz (2005) proved that reporting on internet could facilitate providing, disseminating, and exchanging financial information and it could make necessary confidence in terms of the accuracy of disseminated information on internet. Xiao et al. (2005) proved over $95 \%$ of 100 leading American companies had websites and indicated at least $92 \%$ of their annual reports. Khadaroo (2005) studied 100 companies of Kuala Lumpur Stock Exchange in Malaysia and concluded that, although the number of firms and the kind of information provided on internet was increased, the reported information on internet was of less quality for the users. Chiang and Chia (2005) studied financial information transparency and signaling theory in Taiwan and proved that transparency of financial information in a company maintained a direct relationship with its performance. Khan (2007) studied the factors influencing on internet reporting and stated that 
companies having various activities had used internet reporting the most, and hotels had used internet reporting the least. Troshani and Rao (2007) studied the drivers and inhibitors to XBRL adoption, using convergent interviews and consequently considered three environmental, organizational, and inventive factors as important. Doolin and Troshani (2007) indicated that there was not enough motivation for comprehensive adoption of XBRL in organizations adopting and providing it.

Troshani and Doolin (2007) argued that the primary performers of XBRL's ignorance for sharing their experiences with others could lead to destroying the competitive environment. Doolin and Troshani (2007) proved that outside pressures like competitive environment, client's interests, and society's culture were influential in reporting on internet. CSA (2007) studied 52\% of stock exchange observers in terms of knowledge of internet reporting. The findings implied on lack of practical knowledge and working experience of XBRL in Canadian markets. Premuroso, and Bhattacharya (2008) studied the relationship between company's decisions and applying internet reporting. The results showed that applying this kind of reporting was a sign of information transparency in such firms. Kelton and Yang (2008) concluded from their research study that internet financial reporting might increase the transparency of financial information disclosure. Bonsón et al. (2009) investigated the steps and methods of disseminating XBRL in the US, from 2000 to December 2008. The findings revealed that, despite investments and encouragements of SEC for volunteer applying of XBRL, just 137 firms out of 10000 American companies applied XBRL voluntarily. Kelton and Pennington (2012) studied the effects of information presentation format and content on amateur investors' decision making. They proved that internet users gain more information, comparing others, using less time and effort. Hassas Yegane and Yahya poor (2002) showed that using internet for financial reporting could provide less expense and easier access to companies' information. Arab Mazar Yazdi (2004) considered frequency increase and the quantity of financial and non-financial information disclosure, the possibility of fast information delivery and disseminating in an unlimited circulation, as the benefits for using internet reporting.

Mahdavi poor et al. (2004) studied the relationship between using internet reporting and company's characteristics. They showed that there was a significant relation among internet reporting, company's leverage, and the kind of industry. Arab Mazar Yazdi and Hassani (2006) indicated that internet reporting presents financial information by a standardized way for providing, disseminating and exchanging financial information. Etemadi Seyf et al. (2006) studied the effect of IT on qualitative characteristics of accounting information and concluded that IT influences on increasing the relevance between accounting information and the increase in reliability and competitive capacity. Bozorg et al. (2006) indicated that internet reporting could facilitate information processing through increasing time and expenses; and it could provide information for users, fasters. Arab Mazad Yazdi and Dariani (2006) studied internet reporting safety and introduced XML, XBRL, and XARL and investigated the safety and confidence on web. Farivar Lilan (2007) studied influential factors on audit in terms of using internet reporting and their results show that using developmental financial reporting language leads to less auditing time and expenses; and leads to information accessibility, on the other hand. Khairi (2008) investigated factors of not applying internet reporting language in Iran. He indicated that not having information from XBRL, not having enough knowledge of using XBRL, the language's inappropriateness to Iran, inefficiency of existing reporting method, are among the factors of not using XBRL. Nikoomaram and Shekari (2010) studied the relationship between XBR1 and qualitative characteristics of accounting information. The results indicated that XBRL was relevant to reliability and comparability of accounting information. Mirmojrian and Shahshahni (2010) showed that internet financial reporting could lead to $21 \%$ to $70 \%$ saving in reporting expenses. Abdolahi and Monzavi (2011) attempted to prioritize implementing internet reporting. They indicated that web service scenario via Kodal system was the most appropriate scenario for implementing internet reporting time in Iran. Poorzamani and Sanai (2013) studied the effect of internet financial reporting on stock price in Iran. They showed that the stock price is increased using internet reporting. 


\section{Research Hypotheses}

The main question of this survey is to find out how internet financial reporting influences on the stock price of listed companies in Tehran Stock Exchange. The study tried to understand how the stock price of companies with and without internet financial reporting changes before and after internet financial reporting.

\section{Research Method}

According to its objective, this research is considered an applied research; and according to data gathering method is among descriptive researches. This research is a quasi-experimental research. The research interval is from 2009 to 2013 and the population includes all companies presented their financial reports on websites in this period (experimental group) and companies which have no websites (control group). The indicators of descriptive statistics have been used to describe the population. In this respect, statistical tables, statistical graphs, mean, median, first quartile, third quartile and standard deviation were used. In this paper, research model can be defined in the frame of a quasi-experimental one as shown in Table.1. In this table, $Y_{i j}$ represents stock price in each of test and control groups before and after applying internet reporting in test (experiment) group. Furthermore $X$ is the variable of experiment, stabilization and use of internet financial reporting system within experiment group. Control group used traditional reporting system during the compared period. First index represents pre and post-test, second index represents control or experiment group.

\section{Table 1}

Research conceptual model

\begin{tabular}{lccc}
\hline Description & Pre- Experiment & Experiment & Post- Experiment \\
\hline Experimental Group & $\mathrm{y}_{11}$ & $\mathrm{x}$ & $\mathrm{y}_{21}$ \\
Control Group & $\mathrm{y}_{12}$ & ---- & $\mathrm{y}_{22}$ \\
\hline
\end{tabular}

This part of study deals with the function contrastive analysis of the companies with internet reporting versus before using it. Status of Experiment and control group companies during the first two years after using internet financial reporting compared with the last year of not using it, and is coded as Table 2. In this table, base year is 2011 having zero code. Table 3 compares profit indices changes before paying tax in both groups. According to figures shift in the table, companies without internet financial reporting have less boost trend compared with companies with internet financial reporting. Fig. 1 shows that improvement in firms with internet financial reporting was more than in companies without this sort of reporting. In addition, we have evaluated changes of two groups' operation profit (earning) indices.

Table 2

The Coding of Comparison Years

\begin{tabular}{cccccc}
\hline Year & Code Description & Code & Year & Code Description & Code \\
\hline 2009 & 2 years Before Financial Internet Reporting & -2 & 2012 & 1 years After Financial Internet Reporting & +1 \\
2010 & 1 years Before Financial Internet Reporting & -1 & 2013 & 2 years After Financial Internet Reporting & +2 \\
\hline
\end{tabular}

Table 3

The Before Tax Earnings Comparison

\begin{tabular}{lcccccc}
\hline \multirow{2}{*}{ Criterion } & \multicolumn{3}{c}{ Mean of Changes Percent } & \multicolumn{2}{c}{ Control Group } \\
\cline { 2 - 7 } & -2 To -1 & -1 To +1 & -1 To +2 & -2 To -1 & -1 To +1 & -1 To +2 \\
\hline Earn Before Tax & $28.02 \%$ & $85.60 \%$ & $57.53 \%$ & $12.27 \%$ & $50.14 \%$ & $161.43 \%$ \\
Earn to Sales & $-20.65 \%$ & $42.25 \%$ & $40.54 \%$ & $-56.90 \%$ & $-145.44 \%$ & $5.74 \%$ \\
Earn to Assets & $-22.90 \%$ & $30.27 \%$ & $25.32 \%$ & $-16.68 \%$ & $-13.47 \%$ & $-5.89 \%$ \\
\hline
\end{tabular}




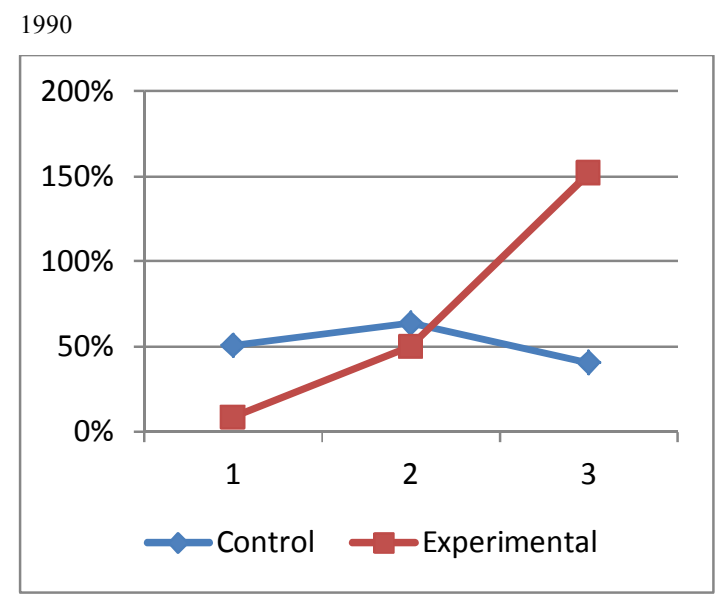

Earning Before Tax Changes

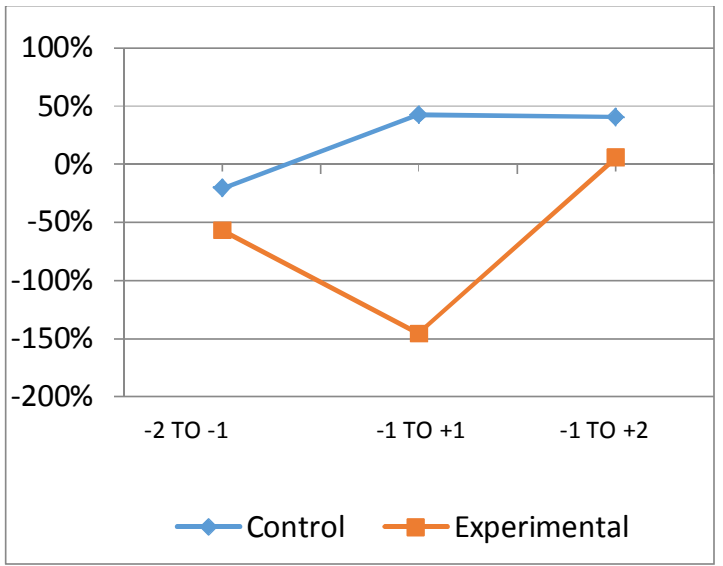

Earning to Assets Ratio Changes

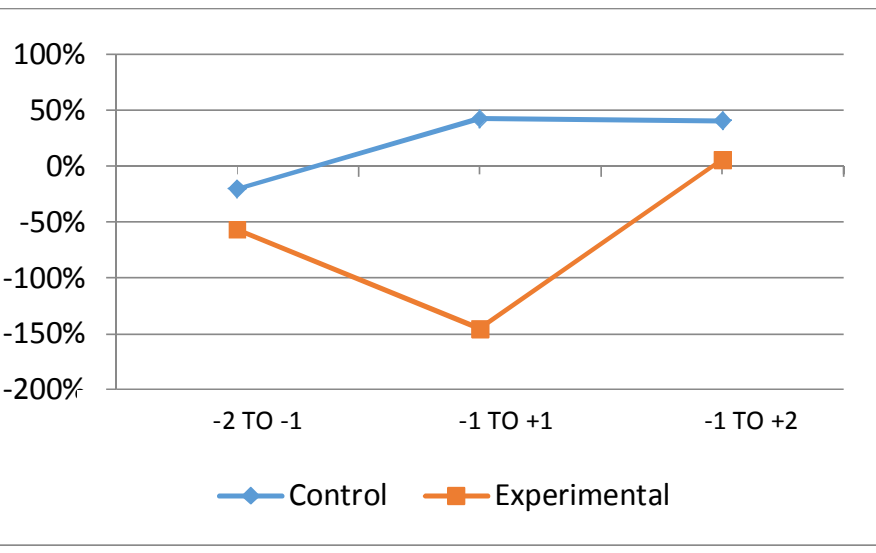

Earning to Sales Ratio Changes

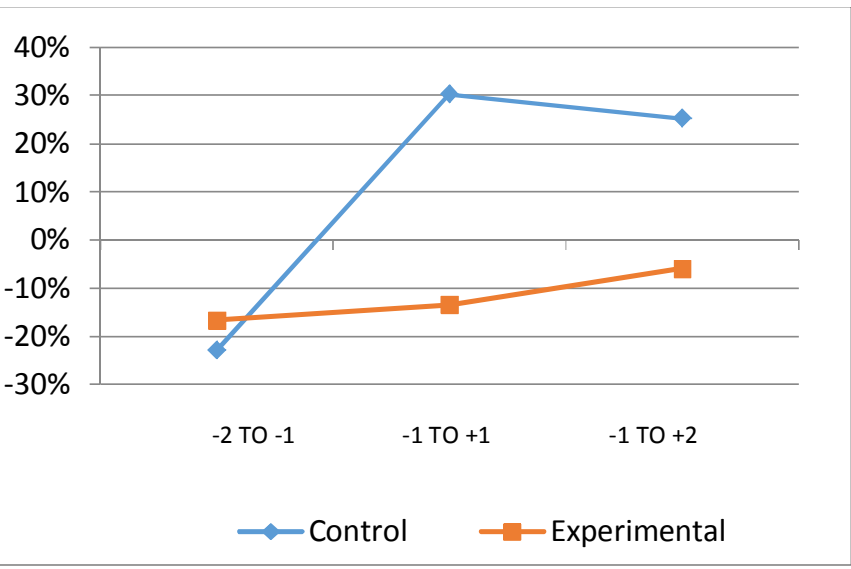

Earning to Assets Ratio Changes

Fig. 1. The summary of some basic statistics

Table 4

The comparison of experiment versus control

\begin{tabular}{lcccccc}
\hline \multirow{2}{*}{ Criterion } & \multicolumn{5}{c}{ Mean of Changes Percent } \\
& -2 To -1 & -1 To +1 & -1 To +2 & -2 To -1 & -1 To +1 & -1 To +2 \\
\hline Operational Earning & $50.71 \%$ & $63.76 \%$ & $40.53 \%$ & $8.42 \%$ & $63.16 \%$ & $151.88 \%$ \\
Op. Earn to Sales & $-16.11 \%$ & $35.68 \%$ & $38.49 \%$ & $-51.55 \%$ & $-92.21 \%$ & $9.22 \%$ \\
Op. Earn to Assets & $-15.97 \%$ & $26.55 \%$ & $28.65 \%$ & $-4.90 \%$ & $-8.88 \%$ & $1.89 \%$ \\
\hline
\end{tabular}

The changes of mean of operational profit (earning) indices after internet financial reporting in experiment group companies were positive and had an increasing trend but in control group, these changes had a descending flow in most cases except operation earning that had an ascending one, during the first year of take-over. Table 4 demonstrates the results. Fig. 2 shows the trend of changes on operational earning indices in companies with internet financial reporting compared with the same trend in companies without internet financial reporting. Analysis of companies' operational earning indices totally indicated that it had a remarkable improvement after using internet financial reporting in experiment group. Table 5 shows activity indices changes of companies with internet financial reporting versus the same companies in control group. Fig. 3 also shows the trend of net earnings changes and activity ratios in both groups. Next, we compare stock prices changes in both groups. Table 6 shows the rate of stock prices changes in companies of control and experiment groups after and before having internet financial reporting. Fig. 4 shows the trend of stock prices changes in control and experiment groups during the years before and after using internet financial reporting. 

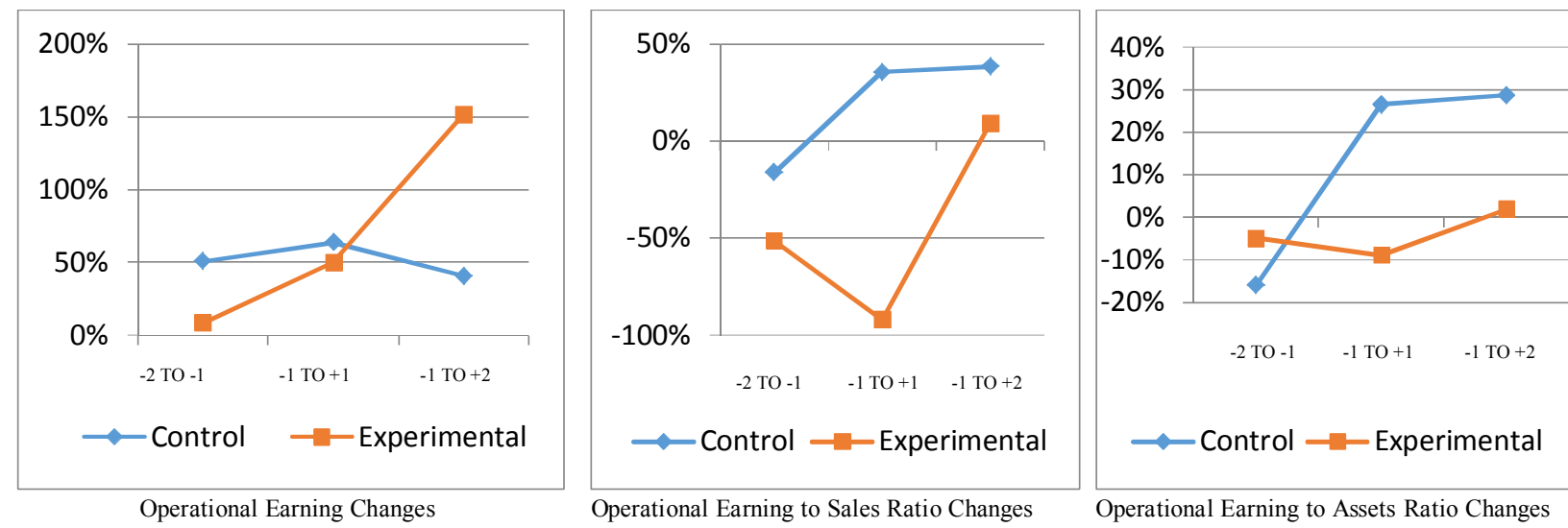

Fig. 2. The trend on operational earnings

Table 5

Net Earnings and Operational Indices Changes for Experimental and Control Group

\begin{tabular}{|c|c|c|c|c|c|c|}
\hline \multirow{3}{*}{ Criterion } & \multicolumn{6}{|c|}{ Mean of Changes Percent } \\
\hline & \multicolumn{3}{|c|}{ Experimental Group } & \multicolumn{3}{|c|}{ Control Group } \\
\hline & -2 To -1 & -1 To +1 & -1 To +2 & -2 To -1 & -1 To +1 & -1 Тo +2 \\
\hline Net Earning & $24.24 \%$ & $91.43 \%$ & $63.99 \%$ & $14.12 \%$ & $54.16 \%$ & $158.92 \%$ \\
\hline Sales & $25.48 \%$ & $4.99 \%$ & $-20.47 \%$ & $9.59 \%$ & $65.51 \%$ & $100.06 \%$ \\
\hline Assets Flow & $-0.21 \%$ & $-4.15 \%$ & $-18.46 \%$ & $9.11 \%$ & $-12.75 \%$ & $-4.36 \%$ \\
\hline Assets Flow & $-71.59 \%$ & $234.57 \%$ & $1677.17 \%$ & $1162.15 \%$ & $-209.51 \%$ & $133.69 \%$ \\
\hline
\end{tabular}
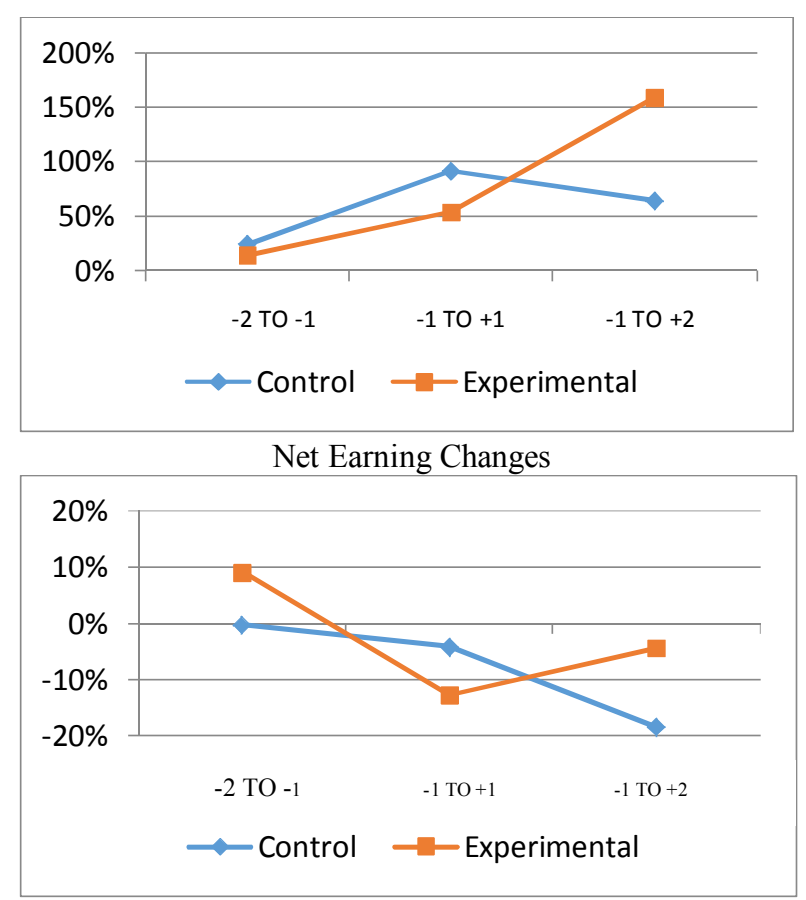

Sales to Assets Ratio Changes
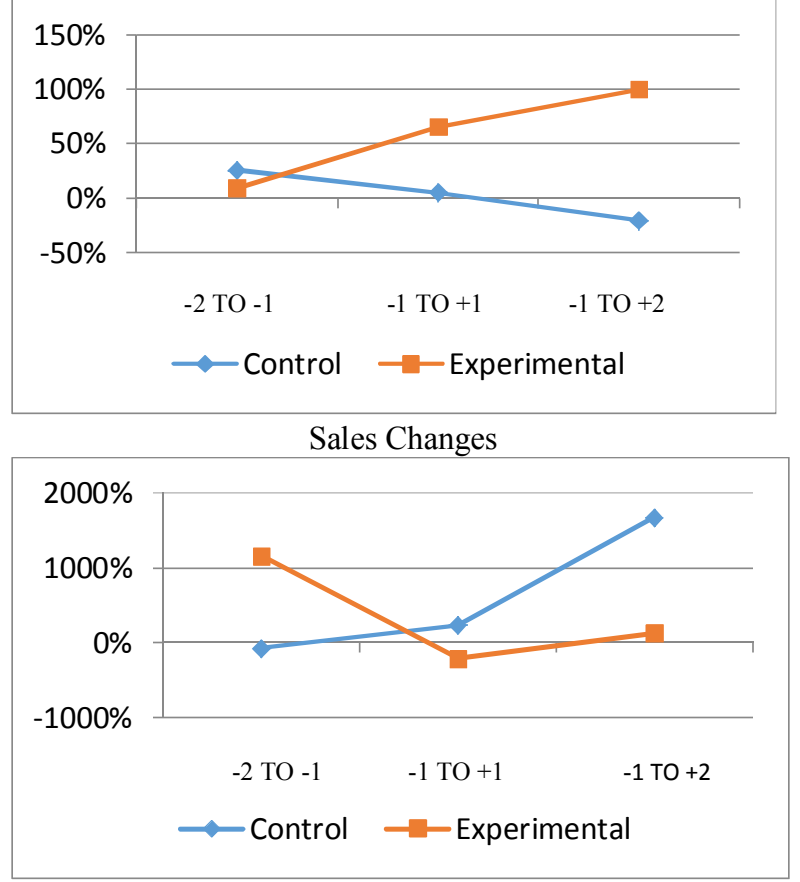

Sales to Current Assets Ratio Changes

Fig. 3. The trend of net earnings changes and activity ratios in both groups

Table 6

Stock Prices Changes for Experimental and Control Group

\begin{tabular}{lcccccc}
\hline \multirow{2}{*}{ Criterion } & \multicolumn{7}{c}{ Mean of Changes Percent } \\
& -2 To -1 & -1 To +1 & -1 To +2 & -2 To -1 & -1 To +1 & -1 To +2 \\
\hline Stock Prices & $-10.18 \%$ & $60.71 \%$ & $13.63 \%$ & $0.00 \%$ & $65.83 \%$ & $5.87 \%$ \\
\hline
\end{tabular}




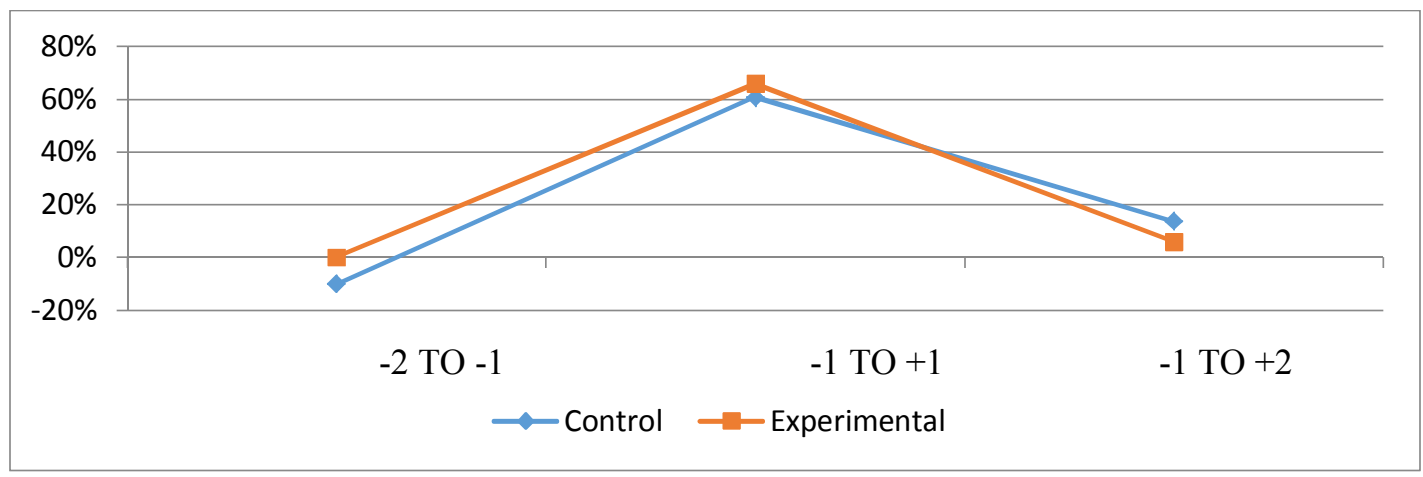

Fig. 4. Stock Prices Changes on Experimental and Control Group

Comparison of stock price changes in both control and experiment group indicates a similar trend and slight differences can be seen in them.

\section{Conclusion}

This paper has evaluated the effects of internet financial reporting on stock prices of the accepted companies in Tehran Stock Exchange. Descriptive statistical method were used to respond the questions, hence to respond each of the above questions, the mean of stock prices was calculated in mentioned companies during the years before and after using internet financial reporting. Then they were compared with each other, therefore mean of stock price changes percent was gained, after using internet financial reporting versus before its use. This process performed for both control and experiment groups. According to research results, Internet reporting did not influences on companies' stock price, and there was no tangible changes in companies using it about their stock price.

\section{References}

Ahmed, K., \& Courtis, J. K. (1999). Associations between corporate characteristics and disclosure levels in annual reports: a meta-analysis. The British Accounting Review, 31(1), 35-61.

Ashbaugh, H., Johnstone, K. M., \& Warfield, T. D. (1999). Corporate reporting on the Internet. Accounting horizons, 13(3), 241-257.

Arab MazarYazdi, M. (2004). Financial reporting in the age of electronic trading. Financial reporting seminar and future transformations, Tehran, Iran [In Persian].

Arab Mazar Yazdi, M., Hassani, E., \& Dariabi, A. (2006). Security in financial reporting services based on the internet. Accountant, 21(174) [In Persian].

Arab MazarYazdi, M. (2005). Web-based financial reporting, future perspective, accountant, monthly periodical of Iran's professional accountants' association, 167 [In Persian].

Abdolahi, A., Monzavi, T. (2011). Identifying and classifying of dismantling scenarios in extendable business reporting language in Iran invest market. Periodical of stock exchange market, 4th year Periodical of Tehran stock exchange, 6 [In Persian].

Arthur, A. (2001). It's raining news: A study of more frequent reporting by large companies.

Allam, A., \& Lymer, A. (2003). Developments in Internet financial reporting: review and analysis, across five developed countries. The international journal of digital accounting research, 3, 6.

García-Borbolla Fernández, A., Larrán Jorge, M., \& López, R. (2005). Empirical evidence concerning SMEs' corporate websites: explaining factors, strategies and reporting. The International Journal of Digital Accounting Research, 5, 6.

Beattie, V. (Ed.). (1999). Business Reporting: The Inevitable Change?. Edinburgh, UK: Institute of Chartered Accountants of Scotland.

Brennan, N., \& Hourigan, D. (1998). Corporate reporting on the Internet by Irish companies.

Bonsón Ponte, E., \& Escobar, T. (2002). A survey on voluntary disclosure on the internet: empirical evidence from 300 European Union companies. The International Journal of Digital Accounting Research, 2, 8.

Beattie, V., \& Pratt, K. (2003). Issues concerning web-based business reporting: an analysis of the views of interested parties. The British Accounting Review, 35(2), 155-187. 
Bager, S., \& Lefrell, A. (2005). Elektoniskt rapportering: En studie av XBRL och dess inverkan på rapporternas jämförbarhet och relevans.

Beattie, V., \& Pratt, K. (2003). Issues concerning web-based business reporting: an analysis of the views of interested parties. The British Accounting Review, 35(2), 155-187.

Boritz, J. E., \& NO, W. G. (2004). CAP Forum on E-Business: Assurance Reporting for XML-Based Information Services: XARL (Extensible Assurance Reporting Language)*. Canadian Accounting Perspectives, 3(2), 207-233.

Bonsón, E., Cortijo, V., \& Escobar, T. (2009). Towards the global adoption of XBRL using International Financial Reporting Standards. International Journal of Accounting Information Systems, 10(1), 46-60.

BozorgAsl, M., \& Valipoorrokni, J. (2006). Knowing concepts and applications of extendable commercial official language. Official Accountants, 9(8) [In Persian].

Craven .B.M \& C.L., Marston (1999). "Financial Reporting on the Internet by Leading UK companies". The European Accounting Review, Vol.8.No.2

Craven, B. M., \& Marston, C. L. (1999). Financial reporting on the Internet by leading UK companies. European Accounting Review, 8(2), 321-333.

Chang, C., \& Jarvenpaa, S. (2005). Pace of information systems standards development and implementation: the case of XBRL. Electronic Markets, 15(4), 365-377.

Chiang, H. T., \& Chia, F. (2005). An empirical study of corporate governance and corporate performance. Journal of American Academy of Business, 6(1), 95-101.

CSA (2007). Notice XBRL Filing Program and Request for Volunteers.

Debreceny, R., \& Gray, G. L. (1999). Financial reporting on the Internet and the external audit. European Accounting Review, 8(2), 335-350.

Debreceny, R., \& Gray, G. L. (1999). Financial reporting on the Internet and the external audit. European Accounting Review, 8(2), 335-350.

Debreceny, R., \& Gray, G. L. (2001). The production and use of semantically rich accounting reports on the Internet: XML and XBRL. International Journal of Accounting Information Systems, 2(1), 47-74.

Doolin, B., \& Troshani, I. (2007). Organizational adoption of XBRL. Electronic Markets, 17(3), 199-209.

Ettredge, M., Richardson, V. J., \& Scholz, S. (2001). The presentation of financial information at corporate web sites. International Journal of Accounting Information Systems, 2(3), 149-168.

Etemadi serif et al. (2006) Evaluating information technology impact on quality characteristics of accounting information. Accounting and Auditing Evaluations, 42, 3-24 [In Persian].

Farivar Lilan, F. (2007). Evaluating helpful factors for accounting in extendible reporting environment. Master thesis in the field of accounting, Azad University of Tehran, Accounting and management department.

Gray, G. L., \& Debreceny, R. (1997, November). Corporate reporting on the internet: opportunities and challenges. In Seventh Asian-Pacific Conference on International Accounting Issues.

Haasbroek, F. (2002). Dissemination of annual report information on the internet by South African companies (Doctoral dissertation, Rand Afrikaans University).

Hassas Delaney, Y., \& Yahya Pour, A.A. (2002). Electronic commercial reporting. Periodical of Management Studies, 33 [In Persian].

Hedlin, P. (1999). The Internet as a vehicle for investor relations: the Swedish case. European Accounting Review, 8(2), 373-381.

Hodge F.D, Kennedy J.J. and Maines L.A. Does Search-Facilitating Technology Improve the Transparency of Financial Reporting?. The Accounting Review 2004; 79(3): 687-703.

Iacovou, C. L., Benbasat, I., \& Dexter, A. S. (1995). Electronic data interchange and small organizations: adoption and impact of technology. MIS Quarterly, 465-485.

Khairi, M. (2008). Evaluating causes for not applying financial extendable reporting language light uranium companies. Master thesis in the field of accounting, Azad University of Tehran, Accounting department.

Khadaroo, M. I. (2005). Business Reporting on The internet in Malaysia and Singapore: A comparative study. Corporate communications: An international journal, 10(1), 58-68.

Kelton, A. S., \& Yang, Y. W. (2008). The impact of corporate governance on Internet financial reporting. Journal of Accounting and Public Policy, 27(1), 62-87.

Kelton, A. S., \& Pennington, R. R. (2012). Internet financial reporting: The effects of information presentation format and content differences on investor decision making. Computers in Human Behavior, 28(4), 11781185.

Louwers, T. J., Pasewark, W. R., \& Typpo, E. W. (1996). The Internet: Changing the way corporations tell their story. CPA JOURNAL, 66, 24-29.

Lymer, A. (1999). Internet and the future of reporting in Europe. European Accounting Review, 8(2), 289-301. 
Larrán Jorge, M., \& Giner, B. (2002). The use of the internet for corporate reporting by Spanish companies. The International Journal of Digital Accounting Research, 2, 8.

Lawson, R., Alcock, C., Cooper, J., \& Burgess, L. (2003). Factors affecting adoption of electronic commerce technologies by SMEs: an Australian study. Journal of small business and enterprise development, 10(3), 265-276.

Lymer, A., \& Debreceny, R. (2003). The auditor and corporate reporting on the internet: challenges and institutional responses. International Journal of Auditing, 7(2), 103-120.

Mahdavi Pour A. (2004). Effective factors on revealing financial information through internet in websites of accepted companies in Tehran [In Persian].

Mirmojrian, H., \& and Shahshahni, S. M. H. (2010). Decision-making effectiveness in financial reporting within the global vast environment, Accountant Magazine, 35 [In Persian].

Marston, C., \& Leow, C. Y. (1998, April). Financial reporting on the Internet by leading UK companies. In 21 st Annual Congress of the European Accounting Association, Antwerp, Belgium.

Marston, C., \& Polei, A. (2004). Corporate reporting on the Internet by German companies. International Journal of Accounting Information Systems, 5(3), 285-311.

Nikoomaram, H., \& Shekari, N. (2010). Relating extendable financial reporting pleaded the characteristics of accounting information quality from senior accountants' viewpoint in accepted companies of stock exchange markets. Management Accounting Magazine, 3(6) [In Persian].

Petravick, S., \& Gillett, J. (1996). Financial reporting on the world wide web. Management Accounting, 78, 26-29.

Pirchegger, B., \& Wagenhofer, A. (1999). Financial information on the internet: a survey of the homepages of Austrian companies. European Accounting Review, 8(2), 383-395.

Pirchegger, B., \& Wagenhofer, A. (1999). Financial information on the internet: a survey of the homepages of Austrian companies. European Accounting Review, 8(2), 383-395.

Rotchanakitumnuai, S., \& Speece, M. (2003). Barriers to internet banking adoption: a qualitative study among corporate customers in Thailand. International Journal of Bank Marketing, 21(6/7), 312-323.

Premuroso, R. F., \& Bhattacharya, S. (2008). Do early and voluntary filers of financial information in XBRL format signal superior corporate governance and operating performance?. International Journal of Accounting Information Systems, 9(1), 1-20.

Poorzamani, Z., \& Sanai, F. (2013). "Internet reporting effect on a stock price" scientific - exploratory periodical of financial knowledge of analyzing stock exchange market, Accountant, 6(17) [In Persian].

Simpson, M., \& Docherty, A. J. (2004). E-commerce adoption support and advice for UK SMEs. Journal of Small Business and Enterprise Development, 11(3), 315-328.

Tornatzky, L. G., Fleischer, M., \& Chakrabarti, A. K. (1990). Processes of technological innovation.

Tidd, J., Pavitt, K., \& Bessant, J. (2001). Managing innovation (Vol. 3). Chichester: Wiley.

Ismail, T. H. (2002). An empirical investigation of factors influencing voluntary disclosure of financial information on the internet in the GCC countries. Available at SSRN 420700.

Khan, T. (2007). Internet financial reporting: disclosure about companies on websites. Journal of Business Systems, Governance and Ethics, 2(2), 20-35.

Troshani, I., \& Rao, S. (2007). Drivers and inhibitors to XBRL adoption: A qualitative approach to build a theory in under-researched areas. International Journal of E-Business Research (IJEBR), 3(4), 98-111.

Troshani, I., \& Doolin, B. (2007). Innovation diffusion: a stakeholder and social network view. European Journal of Innovation Management, 10(2), 176-200.

Canadian Institute of Chartered Accountants. (1999). The impact of technology on financial and business reporting. Canadian Institute of Chartered Accountants.

Wallman, S. M. (1997). The future of accounting and financial reporting, part IV:" access" accounting. Accounting Horizons, 11, 103-116.

XIAO, Z. Z., Dyson, J. R., \& Powell, P. L. (1996). The impact of information technology on corporate financial reporting: a contingency perspective. The British Accounting Review, 28(3), 203-227.

Zezhong Xiao, J., John Jones, M., \& Lymer, A. (2005). A conceptual framework for investigating the impact of the internet on corporate financial reporting. The International Journal of Digital Accounting Research, 5,6 .

Yoon, H., Zo, H., \& Ciganek, A. P. (2011). Does XBRL adoption reduce information asymmetry?. Journal of Business Research, 64(2), 157-163. 